\title{
Aktivitas Antimikroba Ekstrak Kulit dan Jantung Pisang Muli (Musa Acuminata) terhadap Bakteri Escherichia coli
}

\author{
Antimicrobial Activity of of Leather Extract and Muli Banana flower (Musa acuminata) Against Escherichia coli bacteria \\ Dewi Sartika*, Novita Herdiana, Suci Nata Kusuma \\ Jurusan Teknologi Hasil Pertanian, Fakultas Pertanian, Universitas Lampung, \\ Jl. Prof. Soemantri Brojonegoro No. 1 Bandar Lampung, Lampung 35145, Indonesia \\ *Email: dewikincai@yahoo.com
}

Tanggal submisi: 17 Juli 2017; Tanggal penerimaan: 25 September 2019

\begin{abstract}
ABSTRAK
Daging ayam merupakan salah satu bahan pangan yang memegang peranan penting sebagai sumber protein hewani dalam pemenuhan kebutuhan gizi masyarakat. Penelitian ini bertujuan untuk (1) mengetahui adanya daya hambat ekstrak kulit dan jantung pisang muli sebagai antimikroba alami dalam menurunkan cemaran Escherichia coli, (2) menentukan konsentrasi terbaik ekstrak kulit dan jantung pisang muli sebagai antimikroba alami untuk menurunkan cemaranEscherichia coli, (3) mengetahui pengaruh penggunaan ekstrak kulit dan jantung pisang muli sebagai antimikroba alami dalam penurunan cemaranEscherichia coli pada daging ayam. Hasil penelitian menunjukkan bahwa ekstrak kulit dan jantung pisang muli memiliki daya hambat sebagai antimikroba alami dalam menurunkan cemaran bakteri Escherichia coli. Hasil penelitian menunjukkan ekstrak kulit pisang muli memiliki daya hambat pertumbuhan bakteri $E$. coli dengan diameter sebesar $6.45 \mathrm{~mm}$ dengan aktivitas antibakteri sedang. Penghambatan ekstrak jantung pisang muli menunjukkan mampu menghambat pertumbuhan bakteri E. coli dengan diameter hambat sebesar $5.63 \mathrm{~mm}$ dengan kategori aktivitas antimikroba sedang. Konsentrasi terbaik ekstrak kulit dan jantung pisang muli sebagai antimikroba alami untuk menurunkan cemaran Escherichia coli yaitu masing-masing konsentrasi ekstrak $100 \%$ pada taraf nyata $5 \%$. Ekstrak kulit dan jantung pisang muli mampu menurunkan cemaran bakteri Escherichia coli pada daging ayam dengan kategori rendah, dengan angka penurunana dari ${ }^{8} \log 1.8$ menjadi ${ }^{7} \log 3.0$ koloni/g (ekstrak kulit pisang) dan ${ }^{8} \log 1.6$ menjadi ${ }^{7} \log 4,4$ (ekstrak jantung pisang). Total penurunan mikrobia oleh ekstrak kulit dan jantung pisang hanya ${ }^{1}$ log cycle dengan kategori kativitas anti bakterinya adalah rendah.
\end{abstract}

Kata kunci: Antimikroba, Escherichia coli; jantung; kulit; pisang muli

\begin{abstract}
Chicken meat is one of the animal food material that plays an important role as a source of animal protein in the fulfillment of the nutritional needs of the community. The aims of this study were to (1) determine the inhibition effect of muli banana peel and flower extract as a natural antimicrobial agent to reduce contamination of Escherichia coli, (2) determine the best concentration of muli banana peel and flower extract as a natural antimicrobial agent in decreasing contamination of Escherichia coli, (3) to investigate the effect of leather extract and flower of muli banana as a natural antimicrobial agent in decreasing contamination of Escherichia coli in chicken meat. The research was divided into two factors. The first treatment factor was banana peel extract. The second treatment factor was concentration of banana flower extract. The result showed that muli banana peel and flower extract had an inhibitory effect as a natural antimicrobial agent in decreasing contamination of Escherichia coli bacteria. Muli banana peel extract was able to inhibit the growth of $E$. coli bacteria. The clear zone that showed as inhibitory zone was $6.45 \mathrm{~mm}$. It was categorized as medium antibacterial activity. Muli banana
\end{abstract}

DOI: http://doi.org/10.22146/agritech.26625

ISSN 0216-0455 (Print), ISSN 2527-3825 (Online) 
flower extract was able to inhibit the growth of $E$. coli bacteria by $5.63 \mathrm{~mm}$ of inhibitory zone significantly $\mathrm{a}_{0.05}$ and was categorized as medium antibacterial activity. The best concentration of muli banana peel and flower extract as a natural antimicrobial agent in decreasing contamination of Escherichia coli was $100 \%$ at $5 \%$ rate level. Muli banana peel and flower extract had a natural antimicrobial agent characteristic on the decrease of Escherichia coli bacteria in chicken meat (low categories). The decrease of $E$. coli content was up to ${ }^{7} \log 3.0$ from ${ }^{8} \log 1.8$ colony/g (banana leather extract treatment) and up to ${ }^{7} \log 4.4$ from ${ }^{8} \log 1.6$ colony/g (banana flower extract treatment). The decreased number was one log cycle only (low categories).

Keywords: Antimicrobial; Escherichia coli; flower; muli banana; peel

\section{PENDAHULUAN}

Daging ayam merupakan salah satu bahan pangan yang memegang peranan penting sebagai sumber protein hewani dalam pemenuhan kebutuhan gizi masyarakat. Permintaan daging ayam berkembang pesat seiring tingginya tingkat konsumsi daging ayam oleh masyarakat. Hal ini didukung dengan data produksi daging ayam tahun 2015 sebesar 2,04 juta ton atau meningkat 5,11\% dibandingkan tahun 2014, dan ratarata konsumsi per kapita daging ayam masyarakat Indonesia tahun 2011-2015 sebesar 4,28 kg/kapita/ tahun (Nuryati dkk., 2015). Adanya peningkatan permintaan daging ayam berdampak pada kasus penyebaran penyakit yang berasal dari pangan asal hewan ke manusia atau foodborne disease (Dewantoro, 2011).

Beberapa mikroorganisme penyebab penyakit yang berasal dari daging ayam (foodborne disease), antara lain: Escherichia coli, Salmonella, Staphylococcus aureus, Camphylobacter sp., dan Clostridium botulinum (Dewantoro, 2011). Menurut Djaafar dan Rahayu (2007), Escherichia coli merupakan kelompok mikroba pembusuk yang dapat mengubah makanan segar menjadi busuk bahkan dapat menghasilkan toksin. Bakteri Escherichia coli patogen dapat menghasilkan enterotoksin yang menyebabkan beberapa kasus diare (Jawetz dkk., 1995). Berdasarkan SNI 3924.1:2009 (BSN, 2009) tentang mutu daging ayam, batas cemaran E. coli untuk pangan adalah $1 \times 10^{1} \mathrm{koloni} / \mathrm{g}$. Hasil penelitian Marliena (2016) menunjukkan bahwa cemaran E.coli pada daging ayam di pasar tradisional dan pasar modern di Kota Bandar Lampung tidak memenuhi SNI karena diatas batas cemaran $E$. coli pada pangan yaitu $1 \times 10^{2} \mathrm{koloni} / \mathrm{g}$. Hasil penelitian Sartika dkk. (2016), menunjukkan cemaran bakteri patogenteridentifikasi pada dagingayamdi pasar tradisional dan pasar modern dengan tingkat cemaran di Pasar Gintung 2,48 $\times 10^{9}$ $\mathrm{CFU} / \mathrm{g}$, Pasar Rajabasa $1,24 \times 10^{9} \mathrm{CFU} / \mathrm{g}$, PasarTamin

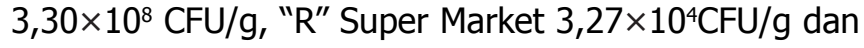
"C" Super Market $1,13 \times 10^{5} \mathrm{CFU} / \mathrm{g}$.
Bakteri E.coli yang mengkontaminasi daging ayam perlu dicegah guna menurunkan jumlah cemaran bakteri patogen. Untuk menekan pertumbuhan bakteri, daging ayam umumnya disimpan dengan cara pendinginan, pembekuan, proses termal (pemanasan), dehidrasi (pengeringan), atau dengan pengawetan menggunakan bahan-bahan pengawet seperti garam, gula, asam, dan berbagai pengawet sintetis atau pengawet kimia (Usmiati, 2010). Kecurangan oleh pedagang dipasaran yang sering terjadi adalah penggunaan bahan pengawet berbahaya seperti formalin dan boraks yang cenderung toksik. Bahan pengawet sintetis maupun bahan kimia yang cenderung toksik tidak direkomendasikan oleh Badan Pengawas Obat dan Makanan (BPOM) karena diduga dapat menimbulkan penyakit kanker (carcinogen agent) (Windiyartono dkk., 2016). Oleh sebab itu bahan pengawdkkami lebih disarankan. Bahan-bahan pengawet alami termasuk di antaranya berasal dari tumbuh-tumbuhan.

Tanaman pisang merupakan salah satu jenis tanaman yang diketahui dapat digunakan sebagai antibakteri karena mampu menghambat aktivitas mikroba. Saraswati (2015), melaporkan bahwa tanaman pisang memiliki banyak kandungan senyawa aktif (metabolit sekunder) yang berperan sebagai senyawa antimikroba diantaranya saponin, tanin, alkaloid, flavonoid, dan fenol. Beberapa penelitian sebelumnya telah membuktikan bahwa tanaman pisang kepok kuning dapat bekerja sebagai antimikroba terhadap beberapa bakteri patogen salah satunya adalah Escherichia coli. Kulit buah pisang memiliki kandungan non-nutrisi, termasuk polifenol dan flavonoid (Lee dkk., 2010). Polifenol merupakan sumber potensial antioksidan dan antimikroba terhadap sejumlah besar bakteri patogen, dan agen potensial untuk mencegah penyakit (Karou dkk., 2005). Jantung pisang mengandung gizi cukup tinggi yaitu protein, vitamin, lemak, dan karbohidrat (Suyanti dan Supriyadi, 2008). Organ jantung pisang memiliki kandungan senyawa aktif (metabolit sekunder) yaitu alkaloid, saponin, tannin, flavonoid, dan total fenol (Mahmood dkk., 2011).Penelitian ini bertujuan untuk (1) mengetahui daya hambat ekstrak kulit 
dan jantung pisang muli sebagai antimikroba alami dalam menurunkan cemaran Escherichia coli, (2) menentukan konsentrasi terbaik ekstrak kulit pisang dan jantung pisang muli sebagai antimikroba alami untuk menurunkan cemaranEscherichia coli, dan (3) mengetahui pengaruh penggunaan ekstrak kulit pisang dan jantung pisang muli sebagai antimikroba alami dalam penurunan cemaranEscherichia coli pada daging ayam.

\section{BAHAN DAN METODE}

\section{Bahan dan Alat}

Bahan utama yang digunakan dalam penelitian ini yaitu kulit pisang dan jantung pisang muli yang diperoleh dari Kecamatan Semaka, Kabupaten Tanggamus, Lampung; daging ayam yang diperoleh dari Pasar Koga Bandar Lampung; kultur bakteri Escherichia coli diperoleh dari koleksi Laboratorium Mikrobiologi Hasil Pertanian, Jurusan Teknologi Hasil Pertanian, FakultasPertanian Universitas Lampung; kertas wattman $(6 \mathrm{~mm})$; bahan-bahan kimia diantaranya mediaMac Conkey Agar (Oxoid), Nutrient Agar (Oxoid), Buffer Pepton Water (Oxoid), dan Nutrient Broth (Merck). Alat utama yang digunakan dalam penelitian ini yaitu oven, vacuum rotary evaporator, hotplate, shaker waterbath, laminar air flow, cawan petri (Normax), autoklaf, inkubator, mikropipet,Erlenmeyer (Pyrex), dan jangka sorong.

\section{Pelaksanaan Penelitian}

Pada penelitian pertama menggunakan ekstrak kulit pisang dengan lima taraf konsentrasi yaitu K1 (20\%), K2 (40\%), K3 (60\%), K4 (80\%), dan K5 (100\%). Penelitian kedua menggunakan ekstrak jantung pisang terdiri dari lima taraf konsentrasi yaitu J1 (20\%), J2 $(40 \%)$, J3 (60\%), J4 (80\%), dan J5 (100\%). Amoxilin $(\mathrm{K}+)$ digunakan sebagai kontrol positif untuk data pembanding. Sediaan ekstrak $100 \%$ dibuat dari 10 $\mathrm{ml}$ ekstrak kental, konsentrasi $80 \%$ (v/v) dibuat dari $8 \mathrm{~mL}$ ekstrak ditambah $2 \mathrm{~mL}$ aquades, konsentrasi $60 \%(\mathrm{v} / \mathrm{v})$ diperoleh dari $6 \mathrm{~mL}$ ekstrak ditambah $4 \mathrm{~mL}$ aquades, konsentrasi $40 \%(\mathrm{v} / \mathrm{v})$ diperoleh dari $4 \mathrm{~mL}$ ekstrak ditambah $6 \mathrm{~mL}$ aquades, konsentrasi 20\% (v/v) diperoleh dari $2 \mathrm{~mL}$ ekstrak ditambah $8 \mathrm{~mL}$ aquades, dan kontrol (negatif) digunakan aquades sebanyak $10 \mathrm{~mL}$.

\section{Preparasi Sampel}

Sampel daging ayam diperoleh dari Pasar Koga Bandar Lampung dan diambil secara acak. Kultur bakteri Echerichia coli diperoleh dari koleksi Laboratorium Mikrobiologi Hasil Pertanian, Jurusan Teknologi Hasil
Pertanian, Fakultas pertanian, Universitas Lampung. Sementara sampel kulit buah dan jantung pisang muli diperoleh dari Kecamatan Semaka, Kabupaten Tanggamus, Lampung. Sampel kulit buah pisang muli dipilih yang sudah matang sempurna atau sudah menguning kulitnya. Sampel kulit pisang dan jantung pisang masing-masing sebanyak $\pm 7 \mathrm{~kg}$ dicuci bersih (terlihat secara fisik), kemudian dikeringkan dengan diangin-anginkan sampai tiris airnya. Setelah itu dipotong kecil-kecil dengan ketebalan $\pm 0,5 \mathrm{~cm} \times 0,5$ $\mathrm{cm}$ kemudian ditimbang beratnya. Berat awal masingmasing sampel yang sudah di potong adalah $\pm 6 \mathrm{~kg}$. Sampel dikeringkan di bawah sinar matahari secara tidak langsung selama 24 jam. Kemudian dilanjutkan pengeringan dengan oven blower pada suhu $50{ }^{\circ} \mathrm{C}$ sampai kadar airnya stabil (kurang dari 10\%) selama 48 jam. Setelah itu simplisia digiling menggunakan blender hingga terbentuk serbuk. Serbuk hasil pengeringan sudah siap untuk dimaserasi. Kemudian di maserasi selama 24 jam menggunakan etanol 96\% sebanyak 2 $\mathrm{L}$ dalam botol tertutup (Ningsih dkk., 2013). Pemilihan etanol sebagai pelarut karena etanol (96\%) lebih efektif dalam menghasilkan jumlah bahan aktif yang optimal. Hal ini sesuai dengan pernyataan Saraswati (2015).

\section{Pembuatan Serbuk}

Pembuatan serbuk dilakukan dengan melakukan kegiatan sortasi sampel sebanyak $600 \mathrm{~g}$ lalu dicuci, ditiriskan, dirajang, dan dikeringkan dengan menggunakan oven $\left(\mathrm{T}=35^{\circ} \mathrm{C}-40^{\circ} \mathrm{C}\right)$ selama 24 -30 jam. Sampel yang telah kering dihaluskan dengan blender hingga berbentuk serbuk.

\section{Pembuatan Ekstrak}

Pembuatan ekstrak yaitu dengan memasukan secara terpisah serbuk yang didapat masing-masing (1 $\mathrm{g}, 2 \mathrm{~g}, 3 \mathrm{~g}, 4 \mathrm{~g}$ ) dalam gelas ukur kemudian ditambahkan pelarut dengan suhu $50^{\circ} \mathrm{C}-60^{\circ} \mathrm{C}$ hingga menunjukkan batas $10 \mathrm{~mL}$. Kemudian divortex selama 2 menit dan disaring hingga mendapatkan ekstrak.

\section{Pembuatan Media NA (Nutrient Agar)}

Media dibuat dengan memasukkan sebanyak 8,4 $\mathrm{g}$ bubuk NA ditambah $4,5 \mathrm{~g} \mathrm{NaCl}$ ke dalam erlenmeyer, lalu dilarutkan dengan menambah $300 \mathrm{~mL}$ aquadest kemudian ditutup dengan aluminium foil hingga rapat dan dipanaskan di atas hot plate hingga larut. Kemudian sterilisasi pada suhu $121{ }^{\circ} \mathrm{C}$ selama 15 menit.

\section{Pembuatan Standar Turbiditas}

Sebanyak 9,95 $\mathrm{mL} \mathrm{H}_{2} \mathrm{SO}_{4} 1 \%$ dimasukkan ke dalam tabung reaksi dan ditambah $0,05 \mathrm{~mL} \mathrm{BaCl}, 1 \%$ 
kemudian divortex. Apabila kekeruhan suspensi uji sama dengan kekeruhan standar, maka suspensi bakteri adalah $1,5 \times 10^{8} \mathrm{CFU} / \mathrm{mL}$ (Sutton, 2011).

\section{Peremajaan Bakteri Uji}

Stok sampel bakteri E. coli dilakukan peremajaa dengan mengambil 1 ose kultur murni kemudian gores secara zig-zagpada agar miring $\mathrm{TSA}+\mathrm{NACl} 1,5$. Inkubasi pada suhu $36^{\circ} \mathrm{C}-37^{\circ} \mathrm{C}$ selama 24 jam.

\section{Pembuatan Suspensi Bakteri}

Koloni bakteri Vibrio sp. yang telah diremajakan pada biakan TSA+NACl 1,5\% umur 24 jam diambil sebanyak 5 ose dimasukkan dalam $5 \mathrm{~mL} \mathrm{NaCl}$ fisiologis $0,85 \%$ dalam tabung reaksi steril dan divortex selama 2 menit. Kekeruhan yang diperoleh kemudian dibandingkan secara visual dengan standar 0,5 Mc Farland. Jika suspensi bakteri uji terlalu keruh, maka dilakukan penambahan larutan $\mathrm{NaCl}$ fisiologis 0,85\%. Jika suspensi bakteri uji kurang keruh, maka dilakukan penambahan beberapa ose bakteri yang telah diremajakan. Suspensi bakteri uji yang telah sesuai dengan standar 0,5 Mc Farland kemudian digunakan untuk uji aktivitas antibakteri (Ningsih dkk., 2013).

\section{Uji Aktivitas Antibakteri dengan Menggunakan Metode Zona Bening}

Kultur bakteri sebanyak $200 \mu \mathrm{L}$ dituang ke dalam cawan petri yang berisi media padat Nutrien Agar (NA). Kemudian diratakan dengan batang $L$. Lempengan agar pada cawan petri selanjutnya didiamkan selama \pm 30 menit. Kertas cakram diameter $6 \mathrm{~mm}$ dicelupkan pada masing-masing ekstrak antibakteri selama \pm 30 detik. Adapun kontrol yaitu kertas cakram yang dicelup dengan pelarut dan cakram antibiotik oksitetrasiklin. Kertas cakram yang telah dicelup masing-masing perlakuan diletakkan pada permukaan lempeng agar sebanyak 3 cakram. Lempengan agar yang telah diberi kertas cakram selanjutnya diinkubasi $\left(\mathrm{T}=36^{\circ} \mathrm{C}-37^{\circ} \mathrm{C}\right.$; $\mathrm{t}=24$ jam). Diameter zona bening yang muncul diukur menggunakan jangka sorong digital.

\section{Metode Perhitungan Penurunan Jumlah Bakteri E. coli Antimikroba Alami}

Udang putih segar disiapkan sebanyak $20 \mathrm{~g}$ lalu di beri perlakuan: 1) ditambahkan E. coli (1 mL) dan 2) ditambahkan E. coli (1 $\mathrm{mL})+$ anti mikroba alami jantung pisang (4 mL), 3) ditambahkan E. coli $(1 \mathrm{~mL})+$ anti mikroba alami kulit pisang (4 mL); dibiarkan 15 menit lalu dimasukkan ke dalam erlenmeyer dan ditambahkan $\mathrm{NaCl}$ 0,85\% hingga $100 \mathrm{ml}$. Penghomogenan selama
2 menit, kemudian dilakukan pengenceran hingga $10^{-8}$. Pembacaan dilakukan dengan metode pour plate dengan menggunakan media selektif mac conkey. Pembacaan dilakukan sebelum dilakukan perlakuan dan sesudah perlakuan. Kemudian inkubasi pada suhu $36^{\circ} \mathrm{C}-37^{\circ} \mathrm{C}$ selama \pm 24 jam. Tampilan E. coli pada media mac conkey adalah merah terang dikelilingi zona keruh.

\section{Metode Penelitian}

Penelitian dilakukan melalui dua tahap secara terpisah. Penelitian pertama mencari konsentrasi terbaik ekstrak antimikroba pada kulit pisang muli. Penelitian kedua mencari konsentrasi terbaik ekstrak antimikroba pada jantung pisang muli. Kosentrasi terbaik yang diperoleh masing-masing digunakan untuk uji penurunan total E.coli pada daging ayam. Masingmasing percobaan menggunakan faktor tunggal dalam Rancangan Acak Kelompok Lengkap (RAKL) sebanyak enam kali ulangan.

\section{Analisis Data}

Data yang didapat dari hasil pengamatan dianalisis kesamaan ragam dengan Uji Bartlett untuk mengetahui kehomogenan data antar ulangan, dan uji Tuckey. Setelah data tersebut homogen, kemudian data dianalisis dengan sidik ragam untuk mendapatkan ragam penduga galat dan untuk mengetahui ada tidaknya pengaruh antar perlakuan. Data dianalisis lebih lanjut menggunakan uji beda nyata terkecil (BNT) pada taraf nyata $5 \%$.

\section{HASIL DAN PEMBAHASAN}

\section{Ekstraksi}

Hasil dari ekstraksi menunjukkan total ekstrak yang didapatkan dari kulit pisang dan jantung pisang muli masing-masing sebanyak $100 \mathrm{~mL}$ dengan persen rendemen $20 \%$ dari $500 \mathrm{~g}$ bahan kering. Hasil uji organoleptik ekstrakkulit pisang dalam etanol 96\%menunjukkan karakteristik warna coklat kehitaman, berbau khas kulit pisang, dan berbentuk cairan kental. Sementara pada ekstrak jantung pisang menunjukkan karakteristik warna coklat kekuningan, berbau khas jantung pisang, dan berbentuk cairan kental. Hasil pengujian derajat keasaman $(\mathrm{pH})$ menunjukkan nilai 6,2 untuk ekstrak kulit pisang dan nilai 7,6 untuk ekstrak jantung pisang. Nilai tersebut menunjukkan sifat asam yang rendah untuk ekstrak kulit pisang, dan netral untuk ekstrak jantung pisang. Hasil simplisia kering dan ekstrak kental kulit dan jantung pisang muli disajikan pada Gambar 1. 


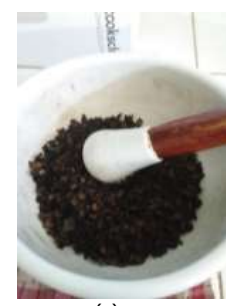

(a)

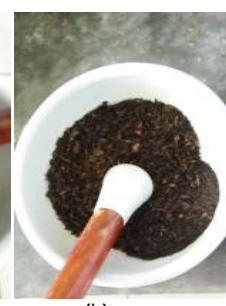

(b)

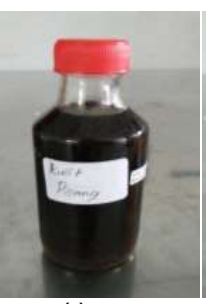

(c)

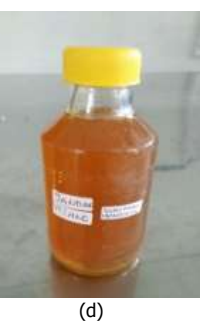

(d)
Gambar 1. Hasil simplisia kering dan ekstrak kental, (a) simplisia kulit pisang, (b) simplisia jantung pisang, (c) ekstrak kulit pisang, (d) ekstrak jantung pisang.

Ekstrak kulit dan jantung pisang muli diperoleh dari proses ekstraksi simplisia yang sebelumnya sudah mengalami proses pengeringan. Pengeringan sampel dilakukan untuk menurunkan kadar air pada sampel sehingga tidak mudah ditumbuhi kapang dan bakteri. Hal ini sesuai pendapat Prasetyo dkk. (2013) bahwa tujuan pengeringan adalah untuk mendapatkan simplisia yang tidak mudah rusak, sehingga dapat disimpan dalam waktu yang lebih lama. Selain itu juga untuk menghentikan aktivitas enzim yang dapat menguraikan lebih lanjut kandungan zat aktif di dalam sampel serta untuk memudahkan dalam hal pengelolaan pada proses selanjutnya (Nuria, 2010). Simplisia yang sudah kering dibuat dalam bentuk serbuk dengan tujuan untuk meningkatkan luas permukaan bahan baku, semakin luas permukaan maka bahan baku pengeringan akan semakin cepat dan kontak pelarut dengan senyawa yang akan diekstrak akan semakin baik. Hal ini akan menyebabkan senyawa aktif yang target akan lebih mudah terekstrak (Gunawan dkk., 2004).

\section{Uji Aktivitas Antimikroba}

\section{Ekstrak kulit pisang muli}

Hasil uji aktivitas antimikroba menunjukkan bahwa ekstrak kulit pisang muli memiliki aktivitas antimikroba terhadap bakteri Escherichia coli. Hal ini dibuktikan dengan terbentuknya daerah bebas bakteri (zona bening) di sekitar kertas cakram. Konsentrasi ekstrak kulit pisang $100 \%$ (K5) memiliki pengaruh paling besar terhadap pertumbuhan bakteri uji jika dibandingkan dengan konsentrasi ekstrak kulit pisang lainnya. Ratarata daerah daya hambat yang terbentuk oleh ekstrak kulit pisang konsentrasi $100 \%$ (K5) sebesar 6,45 mm ini merupakan diameter daerah hambat paling besar dibandingkan dengan konsentrasi ekstrak kulit pisang lainnya. Rata-rata diameter daerah hambat yang terbentuk oleh konsentrasi ekstrak kulit pisang $80 \%$ (K4), 60\% (K3), 40\% (K2), dan 20\% (K1) berturut-turut sebesar 5,99 mm, 5,39 mm, 4,52 mm, dan 3,28 mm, sementara pada konsentrasi $0 \%(\mathrm{~K} 0)$ tidak terdapat zona bening atau diameter daerah hambat.Kontrol positif amoxilin $(\mathrm{K}+)$ paling efektif membentuk zona hambat dengan luas zona hambat sebesar $12,33 \mathrm{~mm}$. Hasil diameter daerah bebas bakteri (zona bening) yang terbentuk di sekitar kertas cakram oleh ekstrak kulit pisang muli terhadap bakteri E.coli dapat disajikan pada Gambar 2.

Saraswati (2015) melaporkan zona hambat yang terbentuk dapat digolongkan menjadi beberapa golongan yaitu antibakteri yang tergolong lemah (zona hambat < $5 \mathrm{~mm}$ ), sedang (zona hambat antara 5-10 mm), kuat (zona hambat antara 10-20 mm), dan tergolong sangat kuat (zona hambat $>20 \mathrm{~mm}$ ). Rata-rata diameter yang terbentuk pada perlakuan K5, K4, dan K3 termasuk dalam kategori hambatan yang tergolong sedang, sementara rata-rata diameter hambatan perlakuan K2 dan K1 termasuk dalam kategori hambatan lemah terhadap bakteri E.coli.

Hasil analisis ragam tidak menunjukkan perbedaan yang signifikan antara konsentrasi, perbedaan tampak jelas antara konsentrasi terendah (20\%) dan konsentrasi tertinggi (100\%). Namun, demikian terdapat kecenderungan peningkatan diameter daerah hambat pertumbuhan bakteri uji seiring dengan peningkatan konsentrasi ekstrak. Hasil uji lanjut BNT menunjukkan perlakuan $\mathrm{K} 1$ sangat berbeda nyata terhadap diameter daerah hambat perlakuan K2, K3, K4 dan K5. Perbedaan besarnya diameter daerah hambat masingmasing konsentrasi dapat disebabkan oleh perbedaan

Tabel 1. Hasil uji lanjut BNT taraf 5\% perlakuan ekstrak kulit pisang muli tehadap diameter daerah hambat bakteri Escherichia coli

\begin{tabular}{ccc}
\hline Perlakuan & $\begin{array}{c}\text { Konsentrasi ekstrak } \\
(\%)\end{array}$ & $\begin{array}{c}\text { Nilai tengah diameter } \\
\text { daerah hambat } \pm \text { sd } \\
(\mathrm{mm})\end{array}$ \\
\hline K1 & 20 & $3.28 \pm 0.53^{\mathrm{c}}$ \\
K2 & 40 & $4.52 \pm 0.51^{\mathrm{b}}$ \\
K3 & 60 & $5.39 \pm 0.72^{\mathrm{ab}}$ \\
K4 & 80 & $5.99 \pm 0.63^{\mathrm{a}}$ \\
$\mathrm{K} 5$ & 100 & $6.45 \pm 0.66^{\mathrm{a}}$ \\
$\mathrm{K}+$ & - & $12.33 \pm 0.00$ \\
\hline
\end{tabular}

Keterangan: Angka yang diikuti huruf yang sama menunjukkan tidak berbeda nyata pada taraf a $5 \%$

K1 = Konsentrasi esktrak kulit pisang 20\%

$\mathrm{K} 2=$ Konsentrasi esktrak kulit pisang $40 \%$

K3 $=$ Konsentrasi esktrak kulit pisang 60\%

K4 = Konsentrasi esktrak kulit pisang 80\%

$\mathrm{K} 5=$ Konsentrasi esktrak kulit pisang $100 \%$

$\mathrm{K}+=$ Kontrol positif (amoxilin) 
besarnya kandungan senyawa aktif yang terdapat pada ekstrak. Menurut Katno dkk. (2009), faktor-faktor yang mempengaruhi uji daya hambat adalah konsentrasi senyawa aktif, kepekaan pertumbuhan mikroba uji, ketebalan dan viskositas medium serta reaksi antara zat aktif dengan medium dan suhu inkubasi. Tabel hasil uji lanjut BNT taraf 5\% diameter daerah hambat oleh ekstrak kulit pisang muli disajikan pada Tabel 1.

Hasil diameter daerah hambat pada masingmasing perlakuan memiliki diameter yang berbeda dikarenakan konsentrasi ekstrak yang digunakan berbeda. Perlakuan K5 yaitu konsentrasi ekstrak 100\% memiliki kandungan senyawa aktif dalam jumlah lebih banyak dari konsentrasi ekstrak lainnya sehingga memiliki kemampuan menghambat bakteri uji lebih besar. Hal ini membuktikan semakin besar konsentrsai ekstrak kulit pisang maka semakin banyak kandungan senyawa aktif antimikroba sehingga hambatan yang dihasilkan semakin besar. Oleh sebab itu, konsentrasi ekstrak kulit pisang 100\% (perlakuan K5) merupakan konsentrasi terbaik karena hambatan yang dihasilkan paling besar.

Penelitian yang dilakukan oleh Saraswati (2015), menunjukkan bahwa ekstrak kulit pisang kepok pada konsentrasi 100.000 ppm dapat menghambat pertumbuhan bakteri Staphylococcus aureus dengan diameter daerah hambat sebesar $12,4 \mathrm{~mm}$. Adanya perbedaan diameter daerah hambat dalam penelitian ini dengan yang dilakukan oleh Saraswati (2015) disebabkan oleh varietas tanaman dan jenis bakteri yang digunakan. Bakteri Staphylococcus aureustermasuk bakteri golongan Gram positif yang dinding selnya tersusun dari peptidoglikan bersifat polar sehingga sangat mudah ditembus oleh senyawa yang bersifat polar, sedangkan bakteri Gram negatif (Escherichia coli) struktur dinding selnya terdiri atas tiga komponen (lipoprotein, lipopolisakarida, dan lipid) sehingga susah untuk ditembus. Hal ini diperkuat oleh pernyataan Nur dkk. (2013) bahwa porin dalam lipoprotein pada membran terluar dinding sel bakteri Gram negatif memiliki sifat hidrofilik yang menyebabkan komponen molekul tidak mudah masuk dalam sel bakteri.

\section{Ekstrak jantung pisang muli}

Hasil analisis ragam aktivitas antimikroba ekstrak jantung pisang tidak jauh berbeda dengan hasil analisis ragam aktivitas antimikroba ekstrak kulit pisang yaitu tidak menunjukkan perbedaan yang signifikan antara konsentrasi $20 \%$ dan $40 \%$, demikian juga antara konsentrasi $60 \%$, $80 \%$, dan $100 \%$. Perbedaan terlihat jelas antara konsentrasi terendah (20\%) dan konsentrasi tertinggi (100\%). Hasil pengukuran diameter daerah hambat oleh ekstrak jantung pisang muli terhadap bakteri $E$. coli disajikan pada Gambar 3.

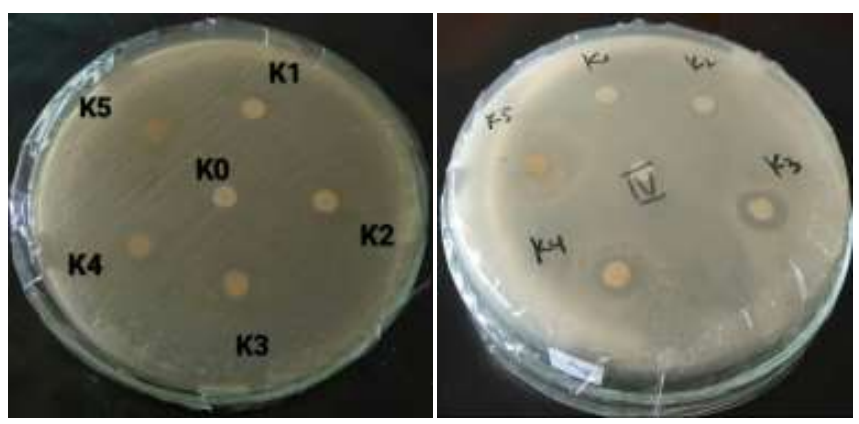

Keterangan:

$\mathrm{J1}=$ Konsentrasi esktrak jantung pisang 20\%

$\mathrm{J} 2$ = Konsentrasi esktrak jantung pisang $40 \%$

$\mathrm{J} 3=$ Konsentrasi esktrak jantung pisang $60 \%$

$\mathrm{J} 4=$ Konsentrasi esktrak jantung pisang $80 \%$

$\mathrm{J} 5=$ Konsentrasi esktrak jantung pisang $100 \%$

$\mathrm{J} 0=$ Kontrol negatif (aquades)

$\mathrm{K}+=$ Kontrol positif (amoxilin)

Gambar 3. Daerah bebas bakteri (zona bening) yang terbentuk di sekitar kertas cakram oleh ekstrak jantung pisang muli terhadap bakteri $E$. coli

Konsentrasi ekstrak jantung pisang $100 \%$ (J5) memiliki rata-rata Diameter Daerah Hambat (DDH) paling besar yaitu sebesar $5,63 \mathrm{~mm}$. Rata-rata diameter daerah hambat yang terbentuk oleh konsentrasi ekstrak kulit pisang $80 \%, 60 \%, 40 \%$, dan $20 \%$ berturut-turut sebesar 4,68 mm, 3,82 mm, 3,48 mm, dan 1,99 mm, sementara pada konsentrasi $0 \%$ (kontrol negatif) tidak terdapat zona bening atau diameter daerah hambat. Kontrol positif amoxilin $(\mathrm{K}+)$ paling efektif membentuk zona hambat dibanding dengan kelima konsentrasi ekstrak jantung pisang muli dengan luas zona hambat sebesar 12,33 mm. Hasil tersebut menunjukkan bahwa semakin besar konsentrasi ekstrak jantung pisang muli yang digunakan maka semakin besar diameter daerah hambat yang terbentuk.

Hasil uji lanjut BNT taraf $5 \%$ perlakuan ekstrak jantung pisang muli tehadap diameter daerah hambat bakteri Escherichia coli dapat dilihat pada Tabel 2 . Hasil uji lanjut BNT menunjukkan perlakuan $\mathrm{J} 1$ sangat berbeda nyata terhadap diameter daerah hambat perlakuan J2, J3, J4 dan J5. Perlakuan J2 sedikit berbeda nyata terhadap diameter daerah hambat perlakuan $\mathrm{J3}$ danberbeda nyata terhadap diameter daerah hambat perlakuan J4 dan J5. Perlakuan J3 sedikit berbeda nyata terhadap diameter daerah hambat perlakuan $\mathrm{J4}$ dan berbeda nyata terhadap diameter daerah hambat perlakuan $\mathrm{J5}$, sementara perlakuan $\mathrm{J4}$ berbeda nyata terhadap diameter daerah hambat perlakuan J5. Hasil diameter daerah hambatpada masing-masing perlakuan memiliki diameter yang berbeda dikarenakan konsentrasi 
Tabel 2. Hasil uji lanjut BNT taraf 5\% perlakuan ekstrak jantung pisang muli tehadap diameter daerah hambat bakteri Escherichia coli

\begin{tabular}{ccc}
\hline Perlakuan & $\begin{array}{c}\text { Konsentrasi } \\
\text { ekstrak (\%) }\end{array}$ & $\begin{array}{c}\text { Nilai tengah diameter } \\
\text { daerah hambat }\end{array}$ \\
\hline J1 & 20 & $1.99 \pm 0.73^{\mathrm{d}}$ \\
$\mathrm{J} 2$ & 40 & $3.48 \pm 0.92^{\mathrm{c}}$ \\
$\mathrm{J} 3$ & 60 & $3.82 \pm 1.06^{\mathrm{bc}}$ \\
$\mathrm{J} 4$ & 80 & $4.68 \pm 1.57^{\mathrm{b}}$ \\
$\mathrm{J} 5$ & 100 & $5.63 \pm 1.66^{\mathrm{a}}$ \\
$\mathrm{K}+$ & & $14.13 \pm 0.00$ \\
\hline
\end{tabular}

Keterangan: Angka yang diikuti huruf yang sama menunjukkan tidak berbeda nyata pada a $5 \%$

$\mathrm{J} 1$ = Konsentrasi esktrak jantung pisang $20 \%$

$\mathrm{J} 2$ = Konsentrasi esktrak jantung pisang $40 \%$

$\mathrm{J3}=$ Konsentrasi esktrak jantung pisang $60 \%$

$\mathrm{J} 4$ = Konsentrasi esktrak jantung pisang $80 \%$

$\mathrm{J} 5=$ Konsentrasi esktrak jantung pisang $100 \%$

$\mathrm{K}+=$ Kontrol positif (amoxilin)

ekstrak yang digunakan berbeda. Sama halnya dengan hasil uji lanjut BNT diameter hambatan ekstrak kulit pisang, bahwa semakin besar konsentrasi ekstrak jantung pisang maka semakin banyak kandungan senyawa aktif antimikroba sehingga efek penghambatan yang dihasilkan semakin besar. Tabel hasil uji lanjut BNT taraf 5\% diameter daerah hambat oleh ekstrak jantung pisang muli disajikan pada Tabel 2.

Berdasarkan penelitian yang dilakukan oleh Ningsih dkk. (2013), diketahui bahwa jantung pisang memiliki potensi sebagai antibakteri dalam menghambat pertumbuhan bakteri $E$. coli dengan diameter zona hambat sebesar $11,4 \mathrm{~mm}$ pada konsentrasi $200 \mathrm{mg} /$ $\mathrm{mL}$. Adanya perbedaan diameter daerah hambat yang didapat dalam penelitian ini dengan yang dilakukan oleh Ningsihdkk. (2013) disebabkan oleh beberapa hal, diantaranya adalah strain bakteri dan varietas tanaman yang digunakan berbeda. Strain bakteri yang berbeda akan memiliki pengaruh yang berbeda pula dalam melawan zat antibakteri meskipun berasal dari species yang sama. Penelitian yang dilakukan oleh Poeloengan dkk. (2007) membuktikan bahwa adanya perbedaan diameter daerah hambat antara bakteri hasil isolasi dengan isolat bakteri ATCC meskipun berasal dari spesies bakteri yang sama. Begitu juga halnya dengan varietas tanaman yang berbeda juga berpengaruh terhadap jenis dan kuantitas zat khasiat antibakteri yang dihasilkan. Menurut Saraswati (2015) diketahui bahwa empat varietas tanaman pisang yang berbeda memiliki total fenol, polifenol, dan alkaloid yang berbeda pula masing-masingnya.

Davis dan Stout (1971) menyatakan bahwa apabila zona hambat yang terbentuk pada uji difusi agar berukuran kurang dari $5 \mathrm{~mm}$, aktivitas penghambatan dikategorikan lemah. Apabila zona hambat berukuran 5 $10 \mathrm{~mm}$ dikategorikan sedang, 10 - $19 \mathrm{~mm}$ dikategorikan kuat dan $20 \mathrm{~mm}$ atau lebih dikategorikan sangat kuat. Berdasarkan hasil pengamatan dan pengukuran diameter daerah hambat ekstrak jantung pisang muli terhadap bakteri uji diketahui bahwa ekstrak jantung pisang mulikonsentrasi $100 \%$ (J5) memiliki aktivitas antibakteri sedang, sementara ekstrak jantung pisang mulikonsentrasi lainnya (J4, J3, J2, dan J1) memiliki aktivitas antibakteri yang lemah terhadap bakteri $E$. coli.

Faktor yang juga berpengaruh terhadap lemah atau tidak adanya kemampuan menekan pertumbuhan bakteri dari ekstrak jantung pisang terhadap pertumbuhan bakteri $E$. coli adalah konsentrasi (kerapatan sel) suspensi bakteri pathogen yang dilawan cukup tinggi (sesuai dengan standar Mc. Farland 0,5 ) yaitu $1,5 \times 10^{8}$ CFU/mL. Menurut Fardiaz (1989) dalam kemampuan suatu zat antimikroba dipengaruhi oleh beberapa faktor salah satunya adalah sifat-sifat mikroba yang meliputi jenis, konsentrasi, umur dan keadaan mikroba. Beberapa penelitian mengenai aktivitas antibakteri suatu zat terhadap antibakteri tertentu biasanya dilakukan pengenceran bakteri sampai konsentrasi bakteri $10^{5}$ dan $10^{6}$. Pernyataan ini juga diperkuat oleh Pelczar and Chan (1988) bahwa semakin banyak jumlah mikroorganisme yang ada maka semakin banyak pula waktu yang diperlukan untuk membunuhnya.

\section{Uji Penurunan Total E.coli pada Daging Ayam}

Hasil uji penurunan total $E$. coli pada daging ayam menunjukkan bahwa penambahan ekstrak kulit pisang dan jantung pisang muli dapat menurunkan cemaran bakteri E. coli pada daging ayam. Hal ini dibuktikan dengan adanya penurunan jumlah $E$. coli pada daging ayam setelah ditambahkan ekstrak antimikroba alami baik oleh ekstrak kulit pisang maupun jantung pisang muli. Hasil perhitungan rata-rata $E$. coli diperoleh dari

Tabel 3. Hasil uji penurunan total E.coli pada daging ayam menggunakan ekstrak kulit dan jantung muli konsentrasi $4 \%$

\begin{tabular}{lcc}
\hline \multirow{2}{*}{ Sampel } & \multicolumn{2}{c}{ Rata-rata E.coli (koloni/gram) } \\
\cline { 2 - 3 } & $\begin{array}{c}\text { Sebelum ditambah } \\
\text { ekstrak (log) }\end{array}$ & $\begin{array}{c}\text { Sesudah ditambah } \\
\text { ekstrak (log) }\end{array}$ \\
\hline Kulit pisang & ${ }^{8} \log 1,8$ & ${ }^{7} \log 3.0$ \\
Jantung pisang & ${ }^{8} \log 1.6$ & ${ }^{7} \log 4.4$ \\
\hline
\end{tabular}


pengukuran total koloni sebanyak tiga kali ulangan. Hasil uji penurunan total E. coli pada daging ayam menggunakan ekstrak kulit pisang dan jantung muli disajikan pada Tabel 3.

Pada Tabel 3 diketahui bahwa rata-rata pertumbuhan $E$. coli sebelum ditambahkan ekstrak kulit pisang sebesar ${ }^{8} \log 1,8$ koloni/g. Setelah dilakukan penambahan ekstrak kulit pisang rata-rata pertumbuhan E. coli turun menjadi ${ }^{7} \log 3.0$ koloni/g. Pada sampel jantung pisang muli diketahui bahwa rata-rata pertumbuhan $E$. coli sebelum ditambahkan ekstrak jantung pisang sebesar ${ }^{8} \log 1.6$ koloni/g. Setelah dilakukan penambahan ekstrak jantung pisang rata-rata pertumbuhan $E$. coli turun menjadi ${ }^{7} \log 4.4$ koloni/g. Dari nilai tersebut terlihat bahwa ekstrak jantung dan kulit pisang mempunyai daya hambat alami terhadap E. coli, dengan kategori rendah (low categories), hanya mampu menurunkan ${ }^{1} \log$ cycle microbia.

Cemaran E. coli pada daging ayam terbukti positif menurun karena pada sampel ekstrak kulit dan jantung pisang muli terdapat senyawa metabolit sekunder yang berperan sebagai senyawa antimikroba. Berdasarkan hasil penelitian yang dilakukan Saraswati (2015) bahwa ekstrak limbah kulit pisang kepok terbukti positif mengandung senyawa metabolit sekunder yaitu alkaloid, flavonoid, saponin, tanin dan kuinon sebagai agen antimikroba. Pernyataan tersebut juga diperkuat oleh Lee dkk. (2010) bahwa kulit buah pisang memiliki kandungan non-nutrisi, termasuk polifenol dan flavonoid. Sama halnya dengan kulit pisang, jantung pisang muli juga mengandung senyawa metabolit sekunder yang berperan sebagai senyawa antimikroba. Hal ini sesuai pernyataan Mahmood dkk. (2011) yang menyatakan bahwa pada organ jantung pisang mengandung senyawa alkaloid, saponin, tanin, flavonoid, dan total fenol.

Hasil total uji penurunan cemaran E. coli pada daging ayam menunjukkan bahwa ekstrak kulit pisang mampu menurunkan cemaran bakteri $E$. coli lebih besar dari ekstrak jantung pisang. Hal ini kemungkinan disebabkan oleh total senyawa metabolit sekunder yang berperan sebagai antimikroba pada masingmasing ekstrak berbeda. Pada ekstrak kulit pisang diduga memiliki total senyawa antimikroba lebih besar daripada ekstrak jantung pisang sehingga kemampuan dalam mencegah pertumbuhan bakteri lebih besar. Kemampuan ekstrak kulit dan jantung pisang dalam menurunkan cemaran bakteri $E$. coli pada daging ayam menunjukkan hasil yang baik, tetapi dalam uji aktivitas antibakteri dikatakan kurang efektif karena memiliki aktivitas antibakteri sedang.

\section{KESIMPULAN}

Hasil penelitian menunjukan bahwa ekstrak kulit dan jantung pisang muli memiliki daya hambat sebagai antimikroba alami dalam menurunkan cemaran bakteri Escherichia coli. Ekstrak kulit pisang muli mampu menghambat pertumbuhan bakteri $E$. coli dengan diameter daerah hambat sebesar $6.45 \mathrm{~mm} \pm 0.66$ dengan kategori aktivitas daya hambat bakteri sedang, begitu juga, ekstrak jantung pisang muli mampu menghambat pertumbuhan bakteri $E$. coli dengan diameter daerah hambat sebesar $5.63 \mathrm{~mm} \pm 1.66$ dengan aktivitas antibakteri sedang. Konsentrasi terbaik ekstrak kulit dan jantung pisang muli sebagai antimikroba alami untuk menurunkan cemaran Escherichia coli yaitu masingmasing konsentrasi ekstrak $100 \%$ pada taraf nyata $5 \%$. Ekstrak kulit dan jantung pisang muli mampu menurunkan cemaran bakteri Escherichia coli pada daging ayam dengan kategori rendah, dengan angka penurunana dari ${ }^{8} \log 1.8$ menjadi ${ }^{7} \log 3.0$ koloni/g (ekstrak kulit pisang) dan ${ }^{8} \log 1.6$ menjadi ${ }^{7} \log 4,4$ (ekstrak jantung pisang). Total penurunan mikrobia oleh ekstrak kulit dan jantung pisang hanya ${ }^{1} \log$ cycle dengan kategori kativitas anti bakterinya adalah rendah.

\section{KONFLIK KEPENTINGAN}

Penulis menyatakan bahwa artikel ini asli hasil penelitian para penulis, hanya dipublikasikan pada jurnal ini, dan tidak ada konflik kepentingan.

\section{DAFTAR PUSTAKA}

Babu, M. A., Suriyakala, M. A., \& Gothandam, K. M. (2012). Varietal impact on phytochemical contents and antioxidant properties of Musa acuminate (banana). J. Pharm. Sci. \& Res., 10, 1950 - 1955.

BSN (Badan Standardisasi Nasional). (2009). SNI 01-39242009 Tentang Mutu Karkas dan Daging Ayam. Jakarta: Badan Standardisasi Nasional.

Davis, W. W. \& Stout, T. R. (1971). Disc plate methods of microbiological antibiotic assay. J.Applied Microbiology, 22(4), $666-670$.

Departemen Kesehatan, RI. (2000). Parameter Standar Umum Ekstrak Tumbuhan Obat, CetakanPertama (hal. 1012). Jakarta: Direktorat Jendral Pengawasan Obat dan Makanan.

Dewantoro, G. I. (2011). Tingkat Prevalensi Escherichia coli dalam Daging Ayam Beku yang Dilalulintaskan Melalui Pelabuhan Penyeberangan Merak. Skripsi. Bogor: Institut Pertanian Bogor. 
Djaafar, T. F. \& Rahayu, S. (2007). Cemaran mikroba pada produk pertanian, penyakit yang ditimbulkan dan pencegahannya. J. Litbang Pertanian, 26, 67 - 75.

Fardiaz, S. (1989). Analisa Mikrobiologi Pangan. Jakarta: Raja Grafindo Persada.

Gunawan, Didik, Mulyani, \& Sri. (2004). Ilmu Obat Alam (Farmakognosi) Jilid I. Jakarta: Penebar Swadaya.

Jawetz, E., Melnick, J. L., \& Adelberg E. A. (1995). Review of Medical Microbiology (hal. 227-230). Los Altos, California: Lange edicalPublication.

Lee, E. H., Yeom, H. J., Ha, M.S., \& Bae, D. H. (2010). Development of banana pell jelly and its antioxidant and textural properties. J. Food Sci. Biotechnol, 19(2), 449-455. http://doi.org/10.1007/s10068-010-0063-5

Mahmood, A., Ngah, N., \& Omar, M. N. (2011). Phytochemicals constituent and antioxidant activities in Musa $x$ paradisiaca flower. European Journal of Scientific Research, 66(22), $311-318$.

Mardaningsih, A. \& Aini, R. (2014). Pengembangan potensi ekstrak daun pandan (Pandanus amaryllifolius Roxb) sebagai agen antibakteri. J. of Pharmaciana, 4(2), 184-192. http://doi.org/10.12928/pharmaciana. v4i2.1577

Marliena, L. (2016). Uji Bakteriologis dan Organoleptik Daging Ayam (Gallusdomesticus) di Pasar Tradisional dan Pasar Modern Kota Bandar Lampung. Skripsi. Lampung: Universitas Lampung.

Ningsih, A. P., Nurmiati, \& Agustien, A. (2013). Uji aktivitas antibakteri ekstrak kental tanaman pisang kepok kuning (Musa Paradisiaca Linn.) terhadap Staphylococcus aureus dan Escherichia coli. Jurnal Biologi Universtas Andalas, 2(3), 207 - 213.

Nur, J., Dwyana, A., \& Abdullah, A. 2013. Biokativitas Getah Pelepah Pisang Ambon Musa paradisiacavar sapientum terhadap Pertumbuhan bakteri Staphylococcus aureus, Pseudomonas aeuroginosa, dan Escherichia coli. Skripsi. Makassar: Universitas Hasanuddin.

Nuria, M.C., (2010). Antibacterial activities from jangkang (Homalocladium platycladum (F.Muell) Bailey) Leaves. Jurnal Ilmu Pertanian, 6(2), 9- 15.

Nuryati, L., Noviati, Waryanto, R., \& Widianingsih, R. (2015). Outlook Komoditas Pertanian Sub Sektor Peternakan (Daging Ayam). Pusat Data dan Sistem Informasi Pertanian Sekretariat Jenderal Kementerian Pertanian. Jakarta.
Pendit, P. A. C., Zubaidah, E., \& Sriherfyna, F. H. (2016). Karakteristik fisik-kimia dan aktivitas antibakteri esktrak daun belimbing wuluh (Averrhoa bilimbi L.). Jurnal Pangan dan Agroindustri, 4(1), 400 - 409.

Pelczar, M. J. \& Chan, E. C. S. (1988). Dasar-Dasar Mikrobiologi Jilid 1. Jakarta: Universitas Indonesia Press.

Poeloengan, Masniari, Andriani, \& Susan, N. M. (2007). Uji daya antibakteri ekstrak etanol kulit batang bungur (Langerstoremia speciosa Pers.) terhadapStaphylococcus aureus dan Eschericia coli secara in vitro. Dalam Seminar Nasional Teknologi Peternakan dan Veteruner, 776 782.

Pradana, D., Suryanto, D., \& Djayus, Y. (2013). Uji daya hambat ekstrak kulit batang rhizophora mucronata terhadap pertumbuhan bakteri Aeromonas hydrophila, Streptococcus agalactiae dan jamur Saprolegnia sp. J. Aquacoastmarine, 2(1), 78 - 92.

Prasetyo \& Inoriah, E. (2013). Pengolahan Budidaya Tanaman dan Obat-Obatan (Bahan Simplisia), 16-19. Bengkulu: Badan Penerbitan Fakuktas Pertanian, Universitas Bengkulu.

Saraswati, F. N., (2015). Uji AKtivitas Antibakteri Ekstrak Etanol 96\% Limbah Kulit Pisang Kepok (Musa Balbisiana) terhadap Bakteri Penyebab Jerawat (Staphylococcus epidermidis, Staphylococcus aureus, dan Propionibacterium acne). Skripsi. Jakarta: UIN Syarif Hidayatullah.

Snyder, C. R., Kirkland, J. J., \& Glajach, J. L. (1997). Practical HPLC Method Development, 2 ${ }^{\text {nd }}$ ed. (hal. 722 - 723). New York: John Wiley and Sons, Lnc.

Usmiati, S. (2010). Pengawetan daging segar dan olahan. Balai Besar Penelitian danPengembangan Pascapanen Pertanian, Bogor. Jurnal Teknologi Sains, 9(3), 46-51.

Windiyartono, A., Rianti, Rr., \& Wannietie, V. (2016). Efektivitas tepung bunga kecombrang (Nicolaia Speciosa Horan) sebagai pengawet terhadap aspek kimia daging ayam broiler. Jurnal Ilmiah Peternakan Terpadu, 4(1), 19 - 23. http://dx.doi.org/10.23960/jipt.v4i1.p\%25p 